2010

\title{
Towards an Ontology of Bob Dylan
}

William J. Richardson

Boston College, william.richardson@bc.edu

Follow this and additional works at: https://fordham.bepress.com/phil_research

Part of the Continental Philosophy Commons, Music Performance Commons, and the Other Film and Media Studies Commons

\section{Recommended Citation}

Richardson, William J., "Towards an Ontology of Bob Dylan" (2010). Research Resources. 43.

https://fordham.bepress.com/phil_research/43

This Article is brought to you for free and open access by the Hermeneutic and Phenomenological Philosophies of Science at DigitalResearch@Fordham. It has been accepted for inclusion in Research Resources by an authorized administrator of DigitalResearch@Fordham.

For more information, please contact considine@fordham.edu. 


\section{Towards an ontology of Bob Dylan}

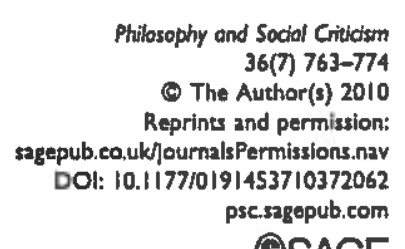

SSAGE

\author{
William J. Richardson \\ Professor of Philosophy Emeritus, Boston College, USA
}

\begin{abstract}
This lecture was first delivered at Tulane University, New Orleans, Louisiana, in 1966. What relevance It may have to the Dylan of 2010 only the reader can say.
\end{abstract}

\title{
Keywords
}

Bob Dylan, Martin Heidegger

Personally I don't know Bob Dylan, but I feel I've met him a thousand times. I never have even seen Bob Dylan, but we talk with one another almost every day. For the Bob Dylan I speak of is not simply the strident folk singer who with the Newport Folk Festival of 1963 skyrocketed to international fame; still less is he the brash, unkempt iconoclast whose songs echo all over the world. It is rather the Dylan behind Bob Dylan, the self into whom Bob Dylan withdraws - and he seems to do this in direct proportion as his fame grows that I would like to reflect on here. For this is the living center of the artist, hidden perhaps even from himself, that is, presumably, the well-spring of his art. This is the self that is attuned to his contemporaries and makes him spokesman for an entire generation. As Joan Baez says, 'Bobby is expressing what I - and many other young people - feel, what we want to say.' At any rate, this is the Bob Dylan that I feel I have met a thousand times in the college students who first introduced me to his records; this is the Bob Dylan that I talk to almost every day as we try to come to grips in one way or another with what it means to be a self, and how to achieve genuine authenticity.

To be perfectly honest, I have no special competence to talk about him. I am neither musician nor musicologist, nor literary critic, nor cultural historian, nor social psychologist. But I like Bob Dylan, I am captured by his songs, and I like, admire and am devoted to the people we deal with every day who respond to him as to their own 
troubadour. If I bring any credentials to a discussion of him, these are no more than what I bring to them - a certain familiarity with another man of our own time, a philosopher by the name of Martin Heidegger. I would like to see if it is possible for one to throw light upon the other.

At first glance, of course, this seems highly improbable, for the only thing common to Bob Dylan and Martin Heidegger would seem to be the fact that they happen to be living at the same time. How do you bring together into a single focus the 30-ish son of a Minnesota appliance dealer, who as a boy ran away from his mining-town home seven times, to be brought back all but once, who quit school after six months of college to live pretty much as a vagabond, whose education, then, is really the experience of life itselfand a relatively short life, at that; how do you relate someone like that, I say, to a man three times his age, the son of a Swabian farmer, who received the best intellectual formation that the German universities could offer, who pursued his studies assiduously until he was older than Dylan is now, who for over 40 years, despite the whirlwind of history that has gone on about him, has lived and worked in the quiet shade of an academic sanctuary, feeding his mind on all the great thinkers of the past from Heraclitus to Edmund Husserl? It is hard to imagine that if they met they could even begin to talk. The mutual suspicion (between youth and age, between American and German, between college dropout and professional intellectual) would freeze them both into silence. Yet if they could be introduced by someone (equally unlikely) like Andrew Fletcher, an 18th-century Scotch politician, maybe the ice would melt, for Fletcher made a remark to which each could respond: 'Give me the making of the songs of a nation and I care not who makes the laws.' Dylan might well respond (at least the early Dylan), 'Yeah, man, all I've been doing is making songs for a nation.' Heidegger could say, 'Sir, I can explain why that is so.' If, then, they got talking and Heidegger could hear Dylan say, 'I don't call myself a poet because I don't like the word - the songs are there ... I just put them down on paper', Heidegger could say, 'Of course, that's the only way poetry is written anyway.' If it went still further and Dylan could loosen up enough to explain why he had run away from home, Heidegger would hear him say: '. .1 I kept running because I wasn't free ... I was still running when I came to New York. Just because you're free to move doesn't mean you're free ... [But] it was running for the sake of running. So I stopped. I've got no place to run from. ... Everybody has to find his own way to be free ...'The restless vagabondage, then, is a ceaseless quest to be free and in that freedom achieve authenticity. But what is this freedom? What is authenticity? Dylan here would have to pick up his guitar, but Heidegger could then find something to say.

I propose first to let Heidegger have his say about what it means to be authentic, to be free. Let us see if he can say anything meaningful not only to Bob Dylan but to the entire generation for whom he sings. The student unrest since the Berkeley affair (1966) - for that matter, most of the college campus movements (civil rights, in part, pacifism, in part, draft card burnings and the like) are all symptoms of a deeper malaise that is sometimes called 'alienation'. Yet for all the complaints about alienation, no one can tell us precisely what it is, still less what is the authenticity to which it is opposed. At a recent meeting of student leaders, a Reed College senior could say no more than that it is the 'real nitty gritty' of life, whatever that may mean. Let us first let Heidegger tell us what he understands by the 'real nitty gritty' of life, then we can let Dylan take up his guitar. 


\section{Authenticity in Martin Heidegger}

Heidegger never ran away from home. But at the age of 18 he left home just as surely as Dylan ever did, and since that time he has been just as much of a vagabond, wandering about in just as restless a search for his own brand of freedom and authenticity. He sometimes speaks with nostalgia of the early years when as a little boy he would make toy boats out of the bark of trees and send them off on make-believe journeys, long before he knew what it meant to embark on a voyage that would leave all familiar shores behind. When did the voyage begin? In his last year of the Gymnasium at Constance, when he was at about the same academic level as a college sophomore.

At that time, a priest-friend lent him a book that was only gathering dust on his own shelf - the doctoral dissertation of Franz Brentano, entitled 'On the Manifold Sense of Being in Aristotle', where 'being' translates the German Seiendes and the Greek on, namely, 'that which is'. We ourselves use the word 'is' (by implication, therefore, refer to 'beings') in countless different ways: this is a lecture, it is in the [Campus Center], it is now 8 p.m., one or another person is listening to it, while the world is going on about us and God is or (if you insist) is not in his heaven. As the word 'is' has a different meaning in each case, so we may say that we ourselves experience different kinds of beings (Seiende, onta), whose only common denominator lies in the fact that each one of them ... is. Brentano's doctoral work had been an examination of the different ways in which Aristotle uses the word on (that which is), In a letter written in 1962, Heidegger describes what transpired in him when he read this study:

... On the title page of his work, Brentano cites Aristotle's phrase to on legetai pollachōs. I translate: 'A being becomes manifest (i.e. with regard to its Being) in many ways." Latent in the phrase is the question that determined my way of thought: what is the pervasive, simple, unified determination of Being that permeates all of its multiple meanings. ... How can they be brought into comprehensible accord?

This accord cannot be grasped without raising and settling the question: Whence does Being as such (not merely beings as beings) receive its determination? ${ }^{1}$ It was with this question that the long way began. In 1959, I had the privilege of a long conversation with Heidegger, and he expanded on this. He said that once the question was raised, he started reading Aristotle himself to find the answer but discovered to his surprise (and chagrin) that Aristotle did not answer the question - still worse, he did not even ask it, but simply supposed that what Being means is clear and neglected to probe the matter further. Simultaneously, then, with the experience of the Being-question as a question was the experience of the neglect of the Being-question in Aristotle, or, as Heidegger puts it, the forgottenness of Being as such.

There was one more element in the initial experience. Since Being is that which accounts for the Is of what is, the human being, who alone can say 'is', must have a privileged access to Being, an openness to it by reason of which he or she can go beyond beings to Being, beyond what is to the Is of what is, even though he or she may overlook Being as that which alone makes it possible to say 'is' in every sentence they utter. Because of this openness to Being (Sein), Heidegger calls human being from the very 
beginning Dasein. It would follow, then, that if one were to investigate the meaning of Being, the only way to go about it would be to explore this comprehension of Being that human beings have in saying 'is', even though perhaps unmindful of it. The quest of the meaning of Being, then, might well begin with an analysis of Dasein itself.

Almost 20 years would pass before this fundamental experience would crystallize into Sein und Zeit (1927). Meantime Heidegger matured philosophically as little by little he groped along the darkened way. When he first went up to the university, he found that the neo-Kantians were in complete command. Locked up in the problems of knowledge and of values, the neo-Kantians could not have cared less about the question of Being. No help from them. But there was some help in the thought of Edmund Husserl. In the first place, he did use the word 'ontology' (albeit 'regional' ontology), which suggested, at least, an openness to the problem of Being. But more important was the method he proposed: phenomenology. Heidegger took the word in a very radical sense: legein to phainomenon, where legein would mean 'to lay out in the open (let appear)' and phainomenon 'that which appears, becomes manifest'. Phenomenology, then, meant to 'let appear that whose nature it is to appear', to let it become manifest as what it is. If the question about Being was the only question for Heidegger worth posing, and if human being itself has an inborn, constantly operative (even though disregarded) comprehension of Being (humans alone can say 'is'), then human being in its Beingcomprehension would be the phenomenon par excellence for his purpose, and the method would be necessarily phenomenological.

There were other influences to be sure. Through Aristotle, Heidegger came to know the whole tradition of Graeco-Roman thought, and Augustine in particular taught him that human being, the phenomenon par excellence, is not something already accomplished but a process continually to-be-achieved. Dilthey helped him to understand the importance of 'man" 's relation to history. Scheler and Kierkegaard, Kant and Hegel and countless lesser figures - all went into the amalgam that finally coalesced in 1927 when Sein und Zeit finally appeared.

Sein und Zeit is one of the 'great books' - much too vast to be treated in any detail in a short space of time. Let us restrict ourselves simply to the consideration of what it tells us about how to become authentic and free. Heidegger never really defines authenticity, but he gives us to understand that since Dasein as a self is a process always to-be-achieved, this self becomes 'properly' (eigentlich) itself, makes this self its 'own' (zueigen), precisely in the achieving of the process, i.e. in accepting itself or endorsing itself as what it is. This endorsement means a choosing of the self by the self. For the self to choose to be the self that it is is to be authentic (eigentlich); to fail to choose to be the self that it is means for it to be inauthentic (uneigentlich). The choice, then, is everything. It is an act of freedom, and since by this choice the self liberates itself unto itself, the choosing achieves the fullness of freedom. But what precisely is the self that so chooses? In what sense is the choice a liberation?

Dasein as a self is that being among beings endowed with a privileged openness to Being. Heidegger sometimes calls it 'transcendence', i.e. a being that of its very nature passes (-scendit) beyond (trans-) beings to their Being. At another time, he speaks of it simply as 'existence', which he later writes as 'ek-sistence', i.e. a being that stands (-sistil) outside of (ek-) itself and toward Being. The structural elements of Dasein, 
conceived as existence, he calls 'existential components' (Existentialien), the phenomenological examination itself 'existential analysis'. But it is only because his quest for the meaning of Being brings him to the study of Dasein's built-in comprehension of Being under the guise of ek-sistence that his effort can be called a "philosophy of ek-sistence' - a far cry, obviously, from what is normally understood by 'existentialism'.

Finally, Heidegger speaks of the self which is Dasein as Being-in-the-World. The reason is this: if one begins to examine Dasein phenomenologically in the everyday condition in which we ordinarily find it, then it appears 'first of all and for the most part' a being immersed among others, absorbed in the day-in-day-out business of life. A closer look, however, reveals that everyday commerce with beings takes place within a certain domain of openness within which Dasein encounters these beings. This open domain is not itself a being like the rest but is rather a horizon within which beings are met. This horizon, then, is what Heidegger understands by the World. If we start the analysis with Dasein in its condition of everydayness, then, that to which Dasein transcends is not Being as Being but Being as World. We can understand, then, how it happens that the analysis of the self as transcendence and ek-sistence is transposed into a new key and becomes through all of Sein und Zeit an analysis of Dasein as to-be-in-the-World.

More specifically, what does the phenomenological analysis of Dasein yield? Briefiy: that it is transcendence, which is finite, whose ultimate meaning is time. Dasein is transcendence. This appears from the close analysis of what it means to-be-in-the-World. First Heidegger examines the World and discovers it to be not simply a horizon within which beings are encountered but a matrix of relationships within which they have meaning. Then he examines what it means to-be-in such a World. Fundamentally it means to disclose the World, and by reason of this disclosure beings within the World are disclosed to Dasein. Heidegger finds three components of this disclosure of the World through Dasein's In-being. The first he calls 'com-prehension', not in any intellectual sense but as a seizure (-prehendere) by Dasein in and as itself (cum-) of the pattern of meaningfulness that the World supplies. The second he calls 'the ontological disposition' (Befindlichkeit), that component of Dasein's structure by which it is affectively disposed to other beings, responds to them, reverberates with them in all its various moods. It is this component - the ontological disposition - which, for one of Heidegger's interpreters, lies at the basis of Dasein's sense of rhythm as it appears in all poetry, and (I would assume) all music - even, perhaps especially, when it emerges as folk-rock. Finally, the third component of Dasein's In-being in the World Heidegger calls 'logos". By this he understands that element in Dasein by reason of which Dasein can articulate its presence in and to the World through language. This is the component which makes possible all language, all poetry, all song.

This complex structure by which Dasein is in-the-World is what the phenomenological analysis discovers in transcendence. We should add here perhaps that Heidegger insists that Dasein is never a solitary in the World. It ek-sists with other Daseins (Dasein is Mitdasein), and this interlacing structure is the basis of all empathy. Be that as it may, transcendence is finite, i.e. it is limited by many different kinds of 'not'. To begin with, Dasein is not its own master - it does not create itself but finds itself (phenomenologically) as a matter of fact in the World. Heidegger calls this Dasein's 'thrownness'. Furthermore, Dasein is not independent of other beings but is related to them and in this 
reference depends on them to be what it is. Again, this referential dependence goes so deep that Dasein tends to become absorbed in other beings, becomes fallen among them ('fallenness') to such an extent that it tends to be oblivious of its openness to Being, to forget its true self. In its everyday condition, Dasein is normally victim of this fallenness, caught up in the throes of what everybody else says and does. Heidegger discerns this condition graphically as a subservience to 'everybody else' - the aboriginal 'In Crowd'.

To be sure, subservience to das Man means anonymity more profound than being in with the In Crowd, for here, at least a man is 'somebody', i.e. one of the In Crowd. But this, at least, is common to them both, a complete abdication of personal responsibility and the total, unreflecting acceptance of what everybody else says and does.

Another kind of 'not' that marks the finitude of Dasein's transcendence is the fact that Being itself, when considered in terms of beings, can only be experienced as not-a-being, Non-being (Nichts). But the deepest 'not' of all is the fact that Dasein cannot be for ever, it is destined to die. So deep is this negativity of death that its sign is upon Dasein from the beginning - not as an event still to come but as already circumscribing the finite Dasein. As soon as it begins to be, it begins to be finite, and the supreme finitude that circumscribes it from the beginning is death. From the first moment of ek-sistence, then, Dasein is Being-into-death. The sum total of all these different types of finitude Heidegger calls 'guilt'. Because it is finite and inasmuch as it is finite, Dasein is ineluctably guilty.

Such, then, are the ingredients of the self - finite transcendence. Thrown among beings it is open to their Being, yet trammeled with finitude, i.e. guilt. But how are these elements experienced in their unity, as pertaining to a single self? It is here that Heidegger describes the phenomenon of anxiety as revealing the true nature of the self. Anxiety is a special mode of the ontological disposition, an affective, non-rational attunement within us. It is different from fear, because fear is always an apprehensive response to something - like a dentist's drill - a being. But in anxiety, the self is not anxious about any one thing but about no-thing in particular, about nothing! Yet not Absolutely Nothing, rather about 'something' quite 'real' that is still not a thing like other things, nor is it situated here or there or anywhere. Anxiety reveals Dasein as exposed to 'something' that is no-thing and no-where. At this moment, the things that have a 'where' around us seem to slip out of our grasp, lose their meaningfulness. We are no longer at home among them. We are alienated from them, as we say - we are alienated, too, from 'everybody else', from the In Crowd with all that it does and says. We discover that there is another dimension in life than the everyday one, a new horizon of which we are ordinarily unaware, yet within which and toward which we truly ek-sist, whether we call this horizon simply the No-thing (Nichts), the World, or even Being itself. Through the phenomenon of anxiety, then, the self becomes aware of itself as a unified whole - related to beings within the World, yet open to Being, the World as such - aware, too, of the possibility of accepting the fact that this is what it is (finite transcendence) or of running away from the truth, refusing to know anything except what the In Crowd knows. In other words, the phenomenon of anxiety reveals to Dasein the possibility of choosing to be authentic or not.

But anxiety as such goes no further. It reveals Dasein to itself, but as such it does not call upon Dasein to make the choice to be true to itself. Yet there is such a voice that calls 
to Dasein out of its very depths - a voice that invites Dasein to be liberated from the thralldom of the In Crowd and accept itself as finite transcendence, as openness to Being, shot through, as it is, with ontological guilt. This, for Heidegger, is the voice of conscience. To heed this voice means to say 'yes': yes to its own transcendence, that is, to the fact that it will always be alienated from the In Crowd to the extent that its true abode is not simply on the level of beings alone but is the domain of Being itself; yes to its own finitude, not as if this meant blind surrender to a tragic fate but simply a tranquil resignation to the fact that it is no more than it is. Dasein says 'yes' to itself by what Heidegger calls the act of 'resolve' (Entschlossenheit), the moment when it achieves authenticity.

Dasein is finite transcendence, whose ultimate meaning - i.e. the ultimate source of its unity - is time. As transcending ek-sistence, Dasein is always coming to Being, i.e. Being is coming to it. This coming is Dasein's future. But Being comes to Dasein that already is. This condition of already-having-been is Dasein's past. Furthermore, Being as it comes to Dasein renders all beings present as meaningful to Dasein. This presence is Dasein's present. Future-past-present, these are the components of time. What gives unity to Dasein, then, is the unity of time. To achieve authenticity precisely as temporal, Dasein must accept itself as essentially temporal - yes, and as historical, too.

There is much more to say, of course, but if we are going to get back to Bob Dylan, let us be content with this as a description of authenticity and simply add one more word about freedom. In what sense does Heidegger maintain that to be truly authentic is to be truly free? In the sense that to be one or the other is to be true. What, then, does he mean by truth?

We have all taken 'true and false' tests since the time we were kids. We are given a statement and asked to say whether or not it is 'true'. We say the statement is true when it expresses a judgment that is conformed to a situation of fact, in other words when the judgment so judges a situation to be as it de facto is. But what guarantees this de facto quality of the 'so ... as' relationship? Is it not the discovery by Dasein that the situation is as it is judged to be? More fundamental than conformity is this process of discovery of beings as they are, in their Being. But this process in Dasein which discovers the Being of beings - what is it but the comprehension of Being in Dasein, in other words Dasein's ek-sistence, transcendence itself?

This process of discovering, which is Dasein's transcendence, is the origin of truth as conformity, i.e. original truth. That is why Heidegger can say that Dasein is 'in the truth'. But Dasein's transcendence is finite, it is permeated by a multiple 'not'. For that reason the coming to pass of truth - truth in its origin, original truth - is likewise pervaded by a 'not'. Consider, for example, that aspect of Dasein's negativity which we called 'fallenness', i.e. Dasein's buitt-in drag towards beings that propels it toward inauthenticity by inclining it to become a slave of the In Crowd and forget its privilege of transcendence. The process of original truth, too, is fallen among beings. This means that the discovery of beings is always somehow askew. They are discovered, to be sure, but always inadequately and drop back immediately into their previous hiddenness. For Dasein to apprehend a being (ergreifen) is simultaneously to misapprehend it (vergreifen); to uncover (entdecken) is to cover up (verdecken); to discover (erschliessen) is to cover over (verschliessen). This condition of undulant, inescapable obscurity Heidegger calls 
"untruth", '... The full ... sense of the expression "Dasein is in the truth" says simultaneously "Dasein is in the untruth" ... "2 And why? Because transcendence is finite.

Clearly, then, the coming to pass of finite transcendence is the coming to pass of truth in its origin. Now if Dasein achieves authenticity through that gesture of self-acceptance that is called 'resolve', then resolve must be also the eminent mode of truth - but also of untruth. In other words, if by resolve Dasein accepts the finitude of transcendence, it simultaneously consents to the finitude of truth. "... [Dasein] is simultaneously in truth and untruth. This applies in the most "authentic" sense to resolve as authentic truth. [Resolve] authentically makes untruth its very own ...', ${ }^{3}$ i.e. accepts the inescapable finitude of the transcendence which is the basis of truth.

But to do this is to become free. How? In Sein und Zeit, Heidegger uses two formulas with regard to the achieving of freedom. He speaks of 'laying free' and of 'becoming free'. What he means by 'laying free' becomes clear when we recall what he means by phenomenology. As we saw, it means legein (to let-be-seen) to phainomenon (beings whose nature it is to appear). But why should we have to make a special effort to let-be-seen these beings, unless these beings, in appearing as what they are, somehow conceal themselves as what they are? The effort to let them be seen, then, is an effort to liberate them from the obscurity that enshrouds them as what they are - to let them be free in truth. In truth! Recall what we know of the finitude of original truth, namely, that Dasein is in the untruth. As a result, the beings that it illuminates by reason of its comprehension of their Being-structure are so contaminated with the negativity of this illumination that they conceal themselves as they reveal themselves. To let them be seen as what they are means to liberate them as far as possible from this concealment, in order that they may be manifest as what they are in truth. Truth must be wrested (abgerungen) from them; they must be torn away (entrissen), robbed (Raub) from concealment in order that they may be manifest as what they are in truth. This is the only legitimate sense to give to the alpha prefix in the Greek word for truth, a-lettheia: lēthe means concealment, and the alpha prefix suggests the privation of, or liberation from, concealment. To lay something free, then, means to liberate it from obscurity - to let its truth come-to-pass.

What, then, does it mean to become free/to be free? The terminology Heidegger reserves to Dasein itself. As a matter of fact, the expression is used in two ways, and we might see in them two successive moments of the process by which Dasein lays its self free. The first moment of freedom occurs when Dasein is startled out of the complacency of its everyday absorption in beings and realizes for the first time that by its comprehension of Being it passes beyond these beings (including itself) to the process that lets them be (manifest). This occurs in the moment of anxiety when all beings seem to slip away from Dasein and leave it exposed to the 'something' that is No-thing, the horizon of the World. In this moment, Dasein has been laid free, liberated from the obscurity that had hitherto held captive the structures of its own transcendence. In this moment, Dasein's existence is wrested from (alpha prefix) the concealment (-lèthe ) that held it prisoner - it is then clearly a moment of truth (a-letheia).

But only the first moment of truth, for it is only the first moment of freedom. 'Anxiety', says Heidegger, 'reveals in Dasein ... [its] being free for [Freisein firr] the freedom of choosing its self [die Freiheil des Sich-selbst-wahlens] ..." In other words, this first moment of freedom makes possible a second moment in which it can choose to 
accept its self as transcendence that is finite, or to refuse its self by trying to run away from the awesome privilege of transcendence in yielding to the seduction of being In with the In Crowd. In other words, it is free to choose between authenticity and inauthenticity. If it chooses to be inauthentic, it becomes a slave to the In Crowd's world. If it chooses to be authentic, then - and only then - does it become authentically free. This happens, as we saw, when Dasein heeds the voice of conscience, calling it to achieve its self. '... In comprehending this voice,' says Heidegger, 'Dasein is attentive to the most characteristic potentiality of its existence. It has [thereby] chosen its self.' This choice is its resolve. In it Dasein liberates its self unto its self, achieves its self in authenticity, becomes authentically free.

\section{Authenticity in Bob Dylan}

What would Bob Dylan have to say to all that? I suppose he would say it's all one big 'drag'. It would be fruitless, I think, and even dishonest, to try to force Dylan into Heidegger's categories against his will, but at least we can raise the question - though perhaps not settle it - whether Heidegger's insight can throw any light on what Dylan (perhaps unconsciously) is trying to do. For he does not speak for himself. Whether we like him or not, the experience he articulates is with us. He speaks for an entire generation. We must bring whatever reflective power we have to admitting 'that the waters around [us] have grown, for the times they are a-changin".

In the first place, it seems clear that Dylan has a profound awareness of his own self as a self. 'The most important thing I know,' he says, 'I learned from Woody Guthrie. I'm my own person. ... Everything I do and sing and write comes out of me.' There is a 'me'a self still to be achieved - then. The task is an endless one, for he'll 'never finish saying everything [he] feels'.

The self he manifests shows clear signs of the basic structure of Dasein that Heidegger calls the 'existential structure' of Being-in-the-World. It began with a basic exposure to an Openness that is not just the sum total of everything that is, but rather a horizon within which everything that is is supposed to have meaning. What meaning? Didn't he run away from home seven times? 'I ran an' kept runnin', I am still runnin', I guess.' How else explain the restless search for experience: on the road, riding the motorcycle that landed him in the hospital, hitting all the poolrooms ('you can find out a lot about a town by hanging around its poolrooms' - even if you are not especially interested in pool). He seems to have been aware of something beyond everything else - of something that perhaps is No-thing itself. In an interview, he remarked: 'I didn't want to sing anything unspecific. ... [But] there is nothing, absolutely nothing to be specific and obvious about. My older songs were about nothing. The newer ones are about the same nothingonly as seen inside a bigger thing, perhaps called the nowhere.' This no-thing, no-where to which he was exposed - could it not have been, be, the horizon of the World towards which he transcends that comes to expression in his songs?

But he was not alone in that World. He was 'thrown' there among other human beings with whom he soon made common cause at a given epoch of time. Indeed as Umwelt, the world-about, found his voice he became its spokesman and troubadour. This became possible because of the unique form taken in him by that component of Dasein that 
Heidegger calls the 'ontological disposition' (Befindlichkeit). In Dylan it made possible his affective sensibility not only on an individual level but broadly enough to shape the popular culture of his time.

The third component of Dasein's existential structure Heidegger calls Rede, by which he translates the Greek logos (or legein). This has an important function in Dylan. I leave to others the task of analysing his poetic flair and remark only upon the nature of the creative process he describes. Apparently he seeks to let come to expression an experience of the world-about (Umwelt) him that somehow lies beyond his deliberate control. There is an 'otherness' in the lyrics that seem to come to him as if from the outside. 'The songs are there. They exist all by themselves just waiting for someone to write them down. If I don't do it, someone else would.' This suggests in Dylan's experience of the creative process a givenness of the to-be-said that is provocative indeed. How explain this receptivity on his part? Heidegger's analysis of the existential component of legein suggests the power in Dasein to combine the dimension of Being with the specific experience of a given being through the mediation of language. This would confront Heidegger himself with a broader question about the nature of poetry, or rather of poetizing (Dichlen) as such. It will concern him to the end of his way, but we cannot take the question any further here.

What is clear now, at least, is that Heidegger's structural elements of finite transcendence are quite discemible in Bob Dylan. How does he unify them in an attempt to achieve authenticity? Not by his eccentricities, whether of dress or manner of speech. Still less by any affectation that sometimes creeps into his artistic experimentation. One critic wrote: 'Folk singers place great value on "authenticity", and Dylan's use of his hoarse, wounding, affectingly ugly voice is nearly a capsule definition of the term.' I think the matter goes deeper than that. In the most general terms, I think Dylan conceives authenticity to be a deep fidelity to himself - the effort to let himself be completely who he is - to be himself in truth. This can be spelled out in several different ways.

Initially, fidelity to himself means fidelity to his artistic inspiration. He is himself in his work. 'I am my words. ... If I haven't been through what I write about, the songs aren't worth anything.' Writing songs for Dylan is one way to be true to himself. And through the songs he tries to let things be seen as they are. 'I define nothing. Not beauty, not patriotism. I take each thing as it is, without prior rules about what it should be.' The most rigorous phenomenologist in the world could ask for no more honest an effort. And I think one might find in this fidelity to himself, i.e. to his changing experience of the World, a deeper explanation for the changes in his style than caprice, hypocrisy, or crass commercialism. When he broke away from the early protest songs in 'Another Side of Bob Dylan', he remarked: "There aren't any finger-pointing songs in here. ... From now on I want to write from inside me, and to do that I'm going to have to get back to writing like I used to when I was ten - having everything come out naturally.'

It is not only the fact of his songs but their content that reveals Dylan's search for authenticity. Several different aspects are characteristic of the effort. The first theme is his growing empathy with the human condition as such. For Dylan, Dasein is clearly Mitdasein. He is part of the whole human tragedy. His capacity for individual empathy lay at the heart of his protest songs, and despite shifts in style this much has not changed. 'Basically he's in the tradition of all lasting folk music', writes one of his critics. 'I mean, 
he's not a singer of protest so much as he is a singer of concern for people.' And even as the new style arrived, we hear him sing of the 'Chimes of Freedom', as 'tolling for the countless confused, accused, misused, strung-out ones and worse. And for every hung-up person in the whole wide universe.' Along with empathy for all who share the common burdens of humanity there goes a rejection of sham in any form. The theme runs through all of his protest songs - from the ironic 'With God on our side' to the more cynical 'It's easy to see without looking too far / that not much / is really sacred.'

Here certainly is a rejection of the everydayness of the In Crowd's world-about him. And he will have no part of the In-Crowd who take him as their spokesman. This appears particularly in his refusal to make his own any of the 'causes' that have taken his songs as their battle-cry - the cause of 'peace', for example. Asked if he thought it was pointless to dedicate oneself to causes of this type, he replied: "To say "cause of peace" is just like saying "hunk of butter". I mean, how can you listen to anybody who wants you to believe he's dedicated to the hunk and not to the butter?' I take this to mean that he is trying to find his own groping way toward a truth in himself that sloughs off the solecisms of everybody else (das Man). In this regard, I think Heidegger would give him a pass.

In his quest for the authentic, he seems to be increasingly aware of the omnipresent negativity of death. In the first disk (1961), to be sure, most of the songs were not his own, but the choice was his, and 8 out of 13 made reference to death. He does not explain why - the album liner suggests that an earlier illness may have been responsible. But the reason must lie deeper than that, for he returns to the theme again and again. Many of the topical songs deal with death - of a civil rights worker, a prizefighter, a murderer, even the whole world (e.g. 'A hard rain's gonna fall'). Sometimes he seems to rage against death, sometimes to look on it wistfully. In the album liner to "Another Side of Bob Dylan', he describes a little old lady he met in Greece. As she dances to his strumming guitar, "her bandanna flies. I too realize / she will die here / [but, almost with a sigh] my death is unknown.' He seems to realize that to be authentic means he must face up to this ultimate mark of finitude, but how? On one hand, 'I would not want to be Bach, Mozart, Tolstoy, Joe Hill, Gertrude Stein or James Dean - they are all dead.' On the other hand, 'I do know that we're all gonna die someday an' that no death has ever stopped the world.' This is hardly an acceptance of death as death in standard Heideggerian fashion, but there are signs of emerging acknowledgement of its immanence. Talking about why he ran away from home, he once said that Hibbing, Minnesota, was a place where he did not want to die. But later he adds, 'As I think about it now, though, it wouldn't be such a bad place to go back and die in [back where the runnin' began] ... embracin' what I left / an' lovin' it, for I leamed by now / never t'expect / what it cannot give me.'

These themes blend together in a single search for freedom, not simply for himself but for 'all the hung-up people in the whole wide universe'. People keep asking him how to 'change things'. 'I can't tell them how to change things, because there's only one way to change things, and that's to cut yourself off from all the chains' - chains that constrain you from being who you are in truth. For Dylan, as well as for Heidegger, the achieving of the truth of one's self is what makes a human being authentically free.

But for Heidegger Dasein is a finite transcendence, whose ultimate meaning is time, and authenticity must be achieved in a temporal way by dealing appropriately with time. 
This means, to begin with, accepting one's own past. Dylan would love to have been a New Yorker, but, in fact: 'I'm not a New Yorker. I'm North Dakota-MinnesotaMidwestern. I'm that color. I speak that way. I'm from some place called Iron Range. My brains and my feeling come from there.' The primary dimension of time for him, however, is not the past - still less (as for Heidegger) the future - but the present. 'What you're asking me about is the future, my future. I'm the last person in the world to ask about my future.' At another moment, he observes, 'What can I say? There doesn't seem to be any tomorrow. Every time I wake up, no matter in what position, it's always been today. ... I'll just keep doing these different things, I guess.' His concern is with the present, not the future.

But it is a future of only one kind - that of a 'now' that has not yet come. But the future as Heidegger sees it, is more than that - it is that which comes to Dasein in order that beings be present to it now. It is future conceived as Being in ad-vent. And I submit that there is an ad-vent in Dylan's experience that is quite unique. We find it in his remarkably lyrical salute to the mysterious 'Tambourine Man'. ${ }^{6}$ The refrain runs: 'Hey, Mr Tambourine Man, play a song for me, / I'm not sleepy and there is no place I'm goin' to. / Hey, Mr Tambourine Man, play a song for me / In the jingle jangle mornin' I'll come followin' you.'

There are many interpretations of the 'Tambourine Man', of course, not the least common of which is to hear the lyric as a description of a psychedelic trip, where the 'Tambourine Man' would be an ordinary dug pusher. But this interpretation is not inevitable. Personally I prefer to see in the song the whole of Bob Dylan: the "ragged clown', "escapin' on the run' out to the horizon of the World, where 'there are no fences facin". The 'Tambourine Man', then, would suggest Dylan's ad-vent, the Coming to which Dylan himself comes - 'laughin' spinnin' swingin' madly across the sun'. To achieve authenticity, then, means to follow the 'Tambourine Man' out beyond "the twisted reach of crazy sorrow" - 'yes, to dance beneath the diamond sky with one hand wavin' free'.

\section{Conclusion}

How conclude? In the briefest terms, we can say:

1. Heidegger's conception of authenticity as the act of resolve by which Dasein consents to be itself as finite, temporal transcendence can hardly be verified as such in a man as protean as Bob Dylan.

2. But Dylan's experience of authenticity, which we have taken as symbolic of the entire generations to which he has given a voice, is both valid and deep, and presents a clear analogy with how Heidegger conceives it.

3. Familiarity with Heidegger's thought gives us the means of reflecting fruitfully on the meaning of Dylan's experience and might - if given the chance - even help Dylan and those who love that croaking voice to understand themselves.

It might! But it might not! For who, after all, is the 'Tambourine Man' whom the ragged troubadour would follow? Is it simply the archetypal drug dealer that offers (maybe) euphoria - but only for a time and only at a price? Is it simply Ad-vent, i.e. time 
itself - in other words, Heidegger's Being? Or is it human being, humanity itself coming to Dylan and his generation out of an amorphous future? Or is it God, coming to them as Human Being in Time, God-Man time? Who is the 'Tambourine Man'? At this point we open up a different kind of question that obviously cannot be pursued further here. Besides, we all may want to explore it differently and disagree on who the "Tambourine Man' really is. But this much is certain: whoever he is, he better be able to wield a solid tambourine.

\section{Notes}

1. 'Prelace' to William J. Richardson, Heidegger: Through Phenomenology to Thought (The Hague: Nijholf, 1963), p. x.

2. "... Der volle existenzial-ontologische Sint des Satzes: "Dasein ist in der Wahrheit" sagt gleichursprunglich mit: "Dasein ist in der Unwahrheit." "M. Hejdegger, Sein und Zeit (Vittorio Klostermann: Frankfurt am Main, 1949), p. 222; author's translation.

3. "Erschlossen in seinem "Da," halt es sich gleichursprunglich in der Wahrheit und Unwahrheit. Das gill "eigentlich" gerade von der Entschlossenheil als der eigentlichen Wahrheit. Sie eignet sich die Unwahrheit eigentlich zu “; ibid., pp. 298-9; author's translation.

4. '... das Freisein fur die Freiheit des Sich-selbst-wahlens und-ergreifens'; ibid., p. 188; author's translation.

5. '... Das Dasein ist rufverstehend hörig seiner eigensten Existenzmoglichkeil. Es hat sich selbst gewahlt'; ibid., p. 287; author's translation.

6. Copyright 1964, 1965 by Wamer Bros. Inc; renewed 1992, 1993 by Special Rider Music. See also: Bob Dylan Lyrics (New York: Simon \& Schuster, 2006) and Michael Gray, The Bob Dylan Encyclopedia (London and New York: Continuum International, 2006). 